Article

\title{
Sustainable Travel Decision-Making of Europeans: Insights from a Household Survey
}

\author{
Tatjana Mamula Nikolić ${ }^{1, *}$, Sanja Popović Pantić ${ }^{2}$, Ivan Paunović ${ }^{3}$ and Sanja Filipović an $^{4,5}$ \\ 1 Metropolitan University, 11000 Belgrade, Serbia \\ 2 Institute Mihajlo Pupin, University of Belgrade, 11060 Belgrade, Serbia; sanjap.pantic@pupin.rs \\ 3 Rural Region Service Centre (DLR), 67435 Neustadt and der Weinstraße, Germany; ivan.paunovic@dlr.rlp.de \\ 4 Faculty of Business, Singidunum University, 11000 Belgrade, Serbia; sfilipovic@singidunum.ac.rs \\ 5 Institute of Social Sciences, 11000 Belgrade, Serbia \\ * Correspondence: tatjana.mamula@metropolitan.ac.rs
}

check for

updates

Citation: Mamula Nikolić, T.; Pantić, S.P.; Paunović, I.; Filipović, S.

Sustainable Travel Decision-Making of Europeans: Insights from a

Household Survey. Sustainability 2021,

13, 1960. https://doi.org/10.3390/

su13041960

Received: 11 December 2020

Accepted: 1 February 2021

Published: 11 February 2021

Publisher's Note: MDPI stays neutral with regard to jurisdictional claims in published maps and institutional affiliations.

Copyright: (C) 2021 by the authors. Licensee MDPI, Basel, Switzerland. This article is an open access article distributed under the terms and conditions of the Creative Commons Attribution (CC BY) license (https:// creativecommons.org/licenses/by/ $4.0 /)$.

\begin{abstract}
The purpose of this study is to research the antecedents of the sustainable travel decisionmaking of European travelers and thereby identify important lessons for the transition towards sustainable travel and tourism. The study is based on data collected through a representative survey, conducted in five European countries, with a sample of $n=5024$ respondents. The results of descriptive statistics, EFA (Exploratory Factor Analysis) and FA (Factor Analysis) are presented in order to explore sustainable travel decision-making through environmental (policy-related and personal) attitudes and travel mode decision priorities in the European context. Furthermore, the study provides new evidence regarding the under-researched phenomenon of the attitude-behavior gap by presenting a model for the sustainability-oriented decision-making of travelers, including attitudes and travel mode priorities as antecedents. The results confirm the existence of moral licensing in travel decision-making, thereby extending the relevance of this theory into travel and tourism, which has not been done before. The denial of environmental issues is also being researched as regards its interaction with positive environmental attitudes, environmental travel mode priorities and non-environmental travel priorities, thereby advancing our understanding of the interplay between these categories. The interplay between the four categories furthers our understanding of the perplexity of travelers in terms of sustainable travel decision-making.
\end{abstract}

Keywords: sustainable travel and tourism; consumer behavior; pro-environmental behavior; environmental attitudes; travel decision-making

\section{Introduction}

Tourism has become an important part of the global economy, but with consequences for popular destinations and cities, overcrowding being one of the most prominent problems [1,2]. In addition to this, tourists are becoming accustomed to unsustainable forms of travel with high carbon footprints and negative impacts on air quality [3,4]. This type of tourist behavior has harmful effects on the environment. Therefore, the concept of environmentally responsible behavior (ERB) among tourists has been introduced in order to mitigate negative effects to the environment caused by tourist activities [2]. This concept is particularly relevant when bearing in mind that stopping all travel would damage destinations both economically and socially [5]. These problems have become evident in light of the COVID-19 crisis, which has affected the tourism sector in an unprecedented way, but which has also demonstrated that the behavior of travelers regarding aspects other than service satisfaction is a very important field of research. Therefore, understanding ERB, both in regard to regular travel in a regional context as well as all other forms of tourism, is becoming increasingly important and includes new dimensions related to the environment, health, and epidemiology. 
This article contributes to the field of sustainable travel behavior by examining attitudes and travel mode priorities as antecedents of the sustainable travel decision-making. It explores, in detail, both positive and negative environmental attitudes as well as environmental and non-environmental travel priorities as antecedents of travel decision-making. Thereby, the research explores the under researched "middle ground" between these previously often cited dichotomies in sustainable tourism. While the endpoints of these two dichotomies (sustainable-non sustainable) have been well documented and researched, the "middle ground" seems to be missing from the research discourse in sustainable tourism.

In order to define the desirable behavior of tourists-which involves not having a negative impact on the environment - it is important to explore the drivers of environmentally friendly behavior, because different environmentally sustainable behaviors have different drivers. Not littering, for example, may be driven by attitude, but choosing a particular transport mode may be determined by factors such as flexibility, reliability, and safety. In this sense, the presence of suitable infrastructure has been proven to be a prerequisite for including certain transport modes, such as cycling, into the decision-making process $[6,7]$. There are, however, different ways in which travelers and tourists can mitigate their negative impact on the environment, for example, by using sustainable tourism providers, visiting sustainable tourist destinations or supporting government regulations aimed at restricting damaging travel and tourism practices [8]. However, it is important to notice that among all tourist activities, transportation produces the most greenhouse emissions [9]. In this sense, tourists are in a situation where they must decide on various aspects that influence their overall emissions. For example, if they avoid long-haul flights; choose sustainable modes of transport over unsustainable ones; avoid activities that use a lot of energy, such as buying imported food [10,11]; or purchase carbon offsets [12], then they can keep their environmental footprint low. However, their decisions are rooted in their attitudes towards the environment. Various attitudinal beliefs (love for the environment, for example) predict the energy-saving behavior and environmentally sustainable buying behavior of tourists [13]. Led by this motivation, they could make optimal purchasing decisions by buying environmentally labelled products [14]; limit their use of natural resources [5], minimize consumption at the destination [15], and reuse hotel towels [16].

Seven different behaviors with high potential to reduce the environmental footprint of the tourism industry have been identified by Juvan and Dolnicar [17]. These include taking fewer vacations, spending vacations closer to home, offsetting the carbon footprint of a vacation, avoiding unsustainable modes of transport, using tourism providers which are certified as environmentally sustainable, avoiding engaging in harmful vacation activities at the destination and refusing to use the services of unsustainable tourism providers. Certainly, tourists are making these decisions based on their preferences and priorities, and not all of them will undertake all of the listed models of behavior. For example, more and more tourists avoid tourism providers who do not issue electronic tickets, thus contributing to lower emissions associated with printing the tickets. Tourists would rather keep the tickets on their phone. On the other hand, spending vacations close to home is not a mass phenomenon, as tourists still like to explore remote destinations. People rarely make environmentally sustainable vacation choices with the specific intention of keeping their environmental impact as low as possible $[18,19]$. This indicates that apart from the attitudinal factors, environmentally significant behavior depends on personal capabilities, contextual forces and habits. In this sense, tourist behavior in relation to the environment is a rather complex phenomenon. For example, knowing about global warming and climate change does not make people travel less $[18,20]$. It is not only the presence or lack of knowledge about a certain product that encourages/stops tourists from using them, but other factors, such as attitudes, also come into play $[19,20]$. Thereby, both environmental as well as non-environmental attitudes appear to be of relevance for environmentally significant behavior. Additional identified limiting factors include technology, money, convenience, and trust. 
There is a rising trend to develop travel and tourism activities which contribute to sustainable tourism, including heritage tourism, ecotourism, rural tourism, agro-tourism and many others [21]. However, there is a lack of evidence that these choices are made intentionally by tourists in order to protect the environment and travel responsibly. A phenomenon that is often identified in relation to environmental behavior is the so-called attitude-behavior gap, where the cognitive dissonance theory is being deployed to explain this phenomenon $[4,19,22]$. The reason for the identified complexities, and often contradictions, is that mobility is regarded as a fundamental prerequisite for economic development, with massive impacts on the environment. There is mounting evidence on the negative aspects of mobility and travel, including air pollution, noise, congestion, land use, and greenhouse gas emissions [23]. Recent (pre-COVID-19 crisis) estimates predict that passenger transport (in kilometers) in the EU will increase by $42 \%$ by 2050 [24]. This raises the questions among managers of how the negative impacts on the environment will be addressed, and how can more sustainable transport and travel products and services best be created to help mitigate these risks?

\section{Literature Review}

\subsection{Attitudes, Behavior and the Environment}

Consumer attitudes towards the environment and sustainability have been researched in the literature in connection to a wide range of related phenomena. The link between environmental attitudes and behavior seems to attract considerable attention $[25,26]$, with two streams of travel-related research: one stream is focusing on tourism-related travel [27-33]; and the second stream is focusing on commuting travel patterns [34,35]. Tourism-related literature includes a wide range of tourist behavior issues, some of which are related to the environment [7,36-40], while others are not [41,42]. The link between attitudes and behavior has also been researched beyond travel patterns, for understanding consumers attitudes and behavior regarding specific tourism products [43-45], as well as foods [46-51] and household consumption [26,52]. Attitudes and behavior of university students towards environmental knowledge, skills, attitudes and values have also received significant attention $[33,53,54]$.

The TRA (Theory of Reasoned Action) and its more recent and developed version, TPB (Theory of Planned Behavior), are the two most important theories used for explaining environmental behavior [55-58]. TRA posits that behavioral intent is the most relevant predictor of person's behavior, while attitudes towards outcome and subjective social norm act as antecedents of behavioral intention [59]. TPB is an extended approach of TRA and tries to explain behavioral intentions through three groups of antecedents: attitudes, social norms and perceived behavioral control over behavior $[60,61]$. There are also models which attempt to explain tourist behavior through satisfaction which consists of image, attitude and motivation [31].

\subsection{Travel Decision-Making}

Travel decision-making can mean both tourism travel as well as commuting travel. While commuting is a well-defined and narrow category, general tourism can stretch to a wide array of activities. This is the reason why the travel decision-making is a multifaceted field of research trying to uncover various aspects of both travel mode [4] as well as destination choice decision-making [62]. Research has uncovered a wide range of factors and antecedents influencing travel decision-making process: while some older research deals with inhibitors and facilitators of travel choice [63] and the influence of others on the decision-making process [64], newer research tries to uncover the role of generational cohorts, risk, uncertainty and climate change in travel decision-making $[4,62,65]$, as well as factors influencing an intention to revisit a destination [66-68]. However, intention to revisit is often being researched as an extension of satisfaction, rather than a new decision-making process [69]. Research on individual as well as collective, household members' decision-making, has attracted significant attention, as well as the multifaceted 
nature of decision-making and the role of socio-psychological aspects, Internet and habit in the decision-making process [70-72]. The role of ICT in travel decision-making is a growing research field, which deals both with IT-assisted decision making, as well as the impact of interaction, collaboration and content sharing in web 2.0 services, such as social media $[73,74]$. Several models have been constructed in order to help explain travel decision-making: a motivation-opportunity-ability (MOA) model [75], multi-stage travel decision-making (before purchase, at time of purchase, after purchase, after arriving at destination) as well as a model of travel decision making supported by social media (pretrip, during trip, post-trip) [74]. However, there is a paucity of models including both attitudes as well as travel choice alternatives.

\subsection{Behavior of Sustainability-Inclined Tourists}

Sustainable tourist behavior can be driven both by environmental intention of the tourist as well as by other intentions or through a mixture of environmental and other intentions [76]. Therefore, environmental intention can only be researched as a complex phenomenon in the context of travel decision-making by taking into account other factors such as costs, weather, family and friends, travel time and activities $[4,17,23]$. This complexity often leads to an attitude-behavior gap or inconsistency of sustainability-inclined tourists, meaning that a large portion of their sustainability intentions cannot be translated to reality due to constraints of other aforementioned factors [19]. Tourists deploy different strategies in dealing with these inconsistencies: from integration and ignorance, to denial, necessity and guilt, as well as indulgence/fatalism, thereby trying to relieve part of the weight put on them by a discourse of "rationalization of lifestyles" [77,78]. In line with this argument, a large portion of sustainable tourism efforts finds itself actually on the supply side of destination and travel offer development [79-85]. Attempts to locate the tourism customers inside the value chain, in order to clearly delimit impacts and responsibilities in sustainable tourism remain an under-researched domain [86].

Regarding approaches deployed in research on sustainability-oriented tourists, they are as multifaceted as the phenomenon itself: from attempts to measure willingness to pay more for sustainable destinations [87] to identifying the characteristics of green tourists as target markets for destinations [88], all the way to understanding factors contributing to denying and opposing sustainability-related problems in tourism [89]. An important aspect that adds to the complexity of environmental intentions of tourists is the fact that pro-environmental behavior of future tourists when at home significantly differs from their pro-environmental behavior later, at the destination [90].

Theory of planned behavior is not only relevant for determining general attitudes, but is of increasing importance also for pro-environmental behavior and is therefore being used as a basis for further theorizing and development of new models, e.g., by combining it with value-belief-norm theory $[61,91,92]$. Additional modelling approaches include the elements such as perceived value, satisfaction, awareness of climate change, moral responsibility for climate change and environmentally responsible behavior; the impact of perceived sustainability (consisting of economic, cultural and environmental sustainability) on perceived value and satisfaction; the impact of image, attitude and motivation on satisfaction, which then influences future tourist behavior [31,93,94]. Further exploratory research deploys typology creation, in order to differentiate between different types of ecotourists, e.g., hard path tourists vs. soft path tourists [95].

\subsection{Hypothesis Development}

Negative environmental attitudes are an important type of attitudes about the environment and environmental issues. The feeling of powerlessness regarding the evolving issues in sustainable travel and tourism is an often-researched aspect in sustainable tourism, coupled with responsibility minimization by comparing oneself to others $[77,89]$. This issue is being researched through item "I am not willing to do anything about the environment if others don't do the same" (NegAtt1). Denying the urgency of environmental problems is 
also an important issue in sustainability-oriented behavior [96], thereby forming a basis for research item "Environmental impacts are frequently overstated" (NegAtt2). Another form of denial of environmental problems is the minimization of own acts by pointing to others who should be more responsible or by pointing to technology [89], thereby forming the basis for items "Environmental issues should be dealt with primarily by future generations" (NegAtt3) and "Environmental issues will be resolved in any case through technological progress" (NegAtt5). Finally, the dismissal of government actions by opposing additional taxes is another form of negative environmental attitudes [89], thereby laying basis for item "Policies introduced by the government to address environmental issues should not cost me extra money" (NegAtt4). As a conclusion, Hypothesis 1 is proposed:

Hypothesis 1: Unwillingness to do anything about the environment if others don't do the same, viewing environmental impacts as overstated, stance that environmental issues should be tackled by future generations, stance that environmental policies should not cost them additional money, as well as stance that environmental issues should be resolved in any case through technological progress are indicators of negative environmental attitudes.

Opposed to negative attitudes, there are also positive attitudes about the environment and environmental issues. An often-identified approach to resolving environmental issues is that individual actions should lead to collectively more sustainable outcomes [89], thereby forming a basis for item "I am willing to make compromises in my current lifestyle for the benefit of the environment" (PosAtt1). Another important issue deals with overcoming the often-cited dichotomy of economy vs. environment, which does not exist among citizens [96], hence providing basis for item "Protecting the environment is a means of stimulating economic growth" (PosAtt2), that protecting the environment is a means of stimulating economic growth. Having the aforementioned literature and items in mind, Hypothesis 2 is proposed:

Hypothesis 2: Willingness to make compromises in the current lifestyle for the benefit of the environment and stance that protecting the environment is a means of stimulating economic growth are indicators of positive environmental attitudes.

Non-environmental travel mode decision priorities have long been researched in the travel and tourism literature, but are also included in the more recent literature on sustainable travel and tourism. Cost and travel time have been researched as crucial factors for planning travel with regard to sustainable tourism [4]. Comfort and flexibility seem to be a major topic of research in travel, but also regarding new mobility and Information technology solutions in tourism [97-99]. Safety is one of the more important aspects in travel decision-making which depends on the tourist's personal risk propensity and the perceptions about the destinations in the decision set [62]. New information technology has also brought about the major interest in the privacy aspect of new location-based services in tourism [100]. Additional important concerns in non-environmental mode decision priorities include reliability, which primarily refers to a combination of route choice and departure time [101] and reputation, as a decision-making dimension closely related to perceived quality of the service [102]. Availability is an important non-environmental travel mode decision priority, which is thought to be higher the closer to home one travels, and therefore essential, also important for sustainable travel and tourism [4]. Based on the above-mentioned literature discussion, Hypothesis 3 has been proposed:

Hypothesis 3: Cost, travel time, comfort, flexibility, safety, privacy, reliability, availability and reputation are indicators of non-environmental travel mode decision priorities.

The two most important environmentally-oriented travel mode decision priorities are air quality impact and $\mathrm{CO}_{2}$ emissions. Air quality impact has been a matter of high concern regarding travel mode decision making, especially regarding the negative impacts 
of car traffic in city centers [23]. The issue of slow travel which points to the carbon-neutral (or low carbon footprint) forms of travel and tourism is receiving increased attention in the literature $[80,103]$, therefore constituting an important aspect of sustainable travel decision-making. Therefore, Hypothesis 4 has been proposed:

Hypothesis 4: Air quality impact and $\mathrm{CO}_{2}$ emissions are indicators of environmentally-oriented travel mode decision priorities.

\section{Methodology}

The study is based on the data collected through the ENABLE.EU project $(\mathrm{H} 2020$ program) with the aim to better understand key drivers of individual and collective energy choices. Overall, a nationally representative survey has been conducted in eleven project's partner countries and covered three key consumption areas-heating and cooling, mobility and use of electricity, and governance and prosumer's issues related to the energy transition. Data was collected in 2017 and 2018, and the sample has been devised to be representative regarding age, gender and country's administrative division. The part of the survey regarding travel mode decision priorities and environmental (policy-related and personal) attitudes was conducted on a nationally representative sample in 5 countries: Hungary, Italy, Norway, Poland and Spain. Depending on the expert opinion, availability of options, national specifics, and price constraints, each of the local country partners selected different a method for data collection and sampling methodology. The main reason for not conducting an online survey in Hungary, Italy, Poland and Spain in a similar way to Norway was that no nationally representative online sample has been available to the local project partner. A face-to-face interviewing survey using a paper questionnaire with random sampling method (F2F PAPI) was conducted in Hungary and Italy. A face-to-face computer-assisted personalized interview (F2F CAPI) with random sampling method was applied in Poland. Finally, an online survey with quota sampling method was conducted in Norway. In the Table 1, sampling method and sample size per country has been presented. The total sample of participants that were included in data analysis was 5026. The questionnaire and results presented in this research have been a part of a larger European household research with a total of sixty-four questions administered in eleven European countries. However, the implementation of certain parts of the questionnaire hasn't been coherent in all of the participating countries, e.g., questions on environmental attitudes and mobility question have only been administered in Hungary, Italy, Norway, Poland and Spain. Depending on their interest, each partner country could choose whether to include the part on mobility or not.

Table 1. Sampling method and sample size per country.

\begin{tabular}{cccc}
\hline Country & Data Collection & Sampling Methodology & $\boldsymbol{N}$ \\
\hline Hungary & F2F PAPI & Random & 1021 \\
Italy & F2F PAPI & Random & 1025 \\
Norway & Online & Quota & 1221 \\
Poland & F2F CAPI & Random & 1000 \\
Spain & F2F PAPI & Random & 759 \\
\hline
\end{tabular}

The current study deals with only a portion of the whole questionnaire which examines attitudes towards the environment and environmental policies and travel mode decision priorities. According to the main objectives of the research, attitudes towards the environment have been assessed using seven items. The respondents needed to answer how much they agree with statements using a 4-point Likert scale ranging from "strongly disagree" (1) to "strongly agree" (4). The items covered general attitudes towards the environment, towards environmental science, towards environmental policy, towards environmental technology and towards environment-economy link. The socio-demographic profiles of the sample are presented in Table 2. The sample consists of a similar proportion of males (48\%) and 
females (52\%), who are on average 48 years old. They are mainly employed full-time (48\%) or retired $(25 \%)$, with secondary $(55 \%)$ or tertiary education $(28 \%)$.

Table 2. Socio-demographic profile of the sample $(n=5026)$.

\begin{tabular}{|c|c|c|c|c|c|}
\hline Gender & & Education & & Employment & \\
\hline Male & $48 \%$ & $\begin{array}{l}\text { Below } \\
\text { primary }\end{array}$ & $2 \%$ & $\begin{array}{l}\text { Employed } \\
\text { full-time }\end{array}$ & $48 \%$ \\
\hline \multirow[t]{6}{*}{ Female } & $52 \%$ & Primary & $14 \%$ & $\begin{array}{l}\text { Employed } \\
\text { part-time }\end{array}$ & $6 \%$ \\
\hline & & Secondary & $55 \%$ & Unemployed & $5 \%$ \\
\hline & & Tertiary & $28 \%$ & Retired & $25 \%$ \\
\hline & & $\begin{array}{l}\text { No data } \\
\text { provided }\end{array}$ & $1 \%$ & Student & $6 \%$ \\
\hline & & & & Other & $8 \%$ \\
\hline & & & & $\begin{array}{l}\text { No data } \\
\text { provided }\end{array}$ & $1 \%$ \\
\hline
\end{tabular}

In addition to attitudes towards the environment, travel mode decision priorities have been explored via twelve items on a 5-point Likert scale. Respondents were asked to respond with what importance each aspect of travel has when they are deciding between different methods of travel. Full questionnaire statements are presented in the Appendix A Tables 1 and 2, while the methodological basis for the deployment of each item is presented in Appendix A Tables 3 and 4.

The first conducted analysis is Principal component analysis (PCA) in order to identify underlying dimensions in the data. Both attitudinal statements and items related to travel mode decision priorities were included in the analysis. However, since these two questions were asked on different scales (4-point Likert and 5-Point Likert, see Appendix A for further reference), PCA was conducted on standardized values. In order to analyze the relationship between environmental (policy-related and personal) attitudes and travel mode decision priorities, as well as manifest variables that are the greatest determinants (or antecedents) of latent dimensions, first-order factor analysis (FA) was deployed. In the second phase, a second-order factor analysis has been conducted in order to determine how an overall latent variable "Sustainable travel decision making" fits with all the first-order latent dimensions. Software packages SPSS v23 and AMOS v24 have been deployed for data processing and running the two aforementioned statistical procedures.

\section{Results}

Research results confirm that tourists prioritize different factors in their decisions between different methods of travel, as presented in the Table 3: availability of method (4.23), reliability (4.21), safety (4.16) and flexibility (4.00) are the most important factors; travel time (3.96), comfort (3.86), cost (3.73) and air quality impact (3.50) are moderately important factors, while privacy (3.48), $\mathrm{CO}_{2}$ emissions impact (3.48), other (2.94) and reputation (2.85) are the least important factors.

Research results confirm that tourists exhibit different attitudes in relation to the environment. The most common attitudes are (1) "Policies introduced by the government to address environmental issues should not cost me extra money" (3.09) and (2) "I am willing to make compromises in my current lifestyle for the benefit of the environment" (3.01); moderately important are (3) "Protecting the environment is a means of stimulating economic growth" (2.96), (4) "Environmental issues will be resolved in any case through technological progress" (2.50) and (5) "Environmental impacts are frequently overstated" (2.21); the least important attitudes are (6) "Environmental issues should be dealt with primarily by future generations" (2.16) and (7) "I am not willing to do anything about the environment if others don't do the same" (1.96) 
Table 3. Average responses regarding different factors influencing the decision regarding different modes of travel.

\begin{tabular}{cccccc}
\hline & $\boldsymbol{N}$ & Minimum & Maximum & Average & Std. Deviation \\
\hline Cost & 4946 & 1 & 5 & 3.73 & 1.293 \\
Travel time & 4935 & 1 & 5 & 3.96 & 1.157 \\
Comfort & 4945 & 1 & 5 & 3.86 & 1.117 \\
Flexibility & 4887 & 1 & 5 & 4.00 & 1.032 \\
$\quad$ Safety & 4929 & 1 & 5 & 4.16 & 1.035 \\
$\quad$ Privacy & 4830 & 1 & 5 & 3.48 & 1.291 \\
Air quality & 4804 & 1 & 5 & 3.50 & 1.232 \\
$\quad$ impact & & & 5 & 3.48 & 1.252 \\
CO Pmissions $_{\text {impact }}$ & 4769 & 1 & 5 & 4.21 & 0.966 \\
Reliability & 4905 & 1 & 5 & 4.23 & 0.987 \\
Availability of & 4913 & 1 & 5 & 2.85 & 1.489 \\
method & 4684 & 1 & 5 & 2.94 & 1.605 \\
Reputation & 847 & 1 & & &
\end{tabular}

The first step was conducting a principal component analysis on the 19 items with orthogonal Varimax rotation. The Kaiser-Meyer-Olkin measure verified the sampling adequacy for the analysis $(\mathrm{KMO}=0.898)$. Four factors had eigenvalues over Kaiser's criterion of 1 , and taken into account together, could explain $61.6 \%$ of the variance, thereby exceeding the two-thirds threshold for successful PCA. In this sense, both Kaiser's criterion (regarding Eigenvalues over 1) as well as the two-thirds threshold rule indicated that four factors should be retained. The first extracted component explains the majority of variance $(33.7 \%)$ and is related to non-environmental travel mode decision priorities such as flexibility, reliability and availability. The second factor represents $13.8 \%$ of total variance and is associated with environmental travel mode decision priorities, such as air quality impact and $\mathrm{CO}_{2}$ emissions impact. Interestingly, one more aspect when choosing methods of travel is highly saturated on the second factor-reputation. The third factor is named Negative environmental policy attitudes, since items saturated on this factor are related to negative environmental (policy-related and personal) attitudes. The third factor explains significantly less variance, compared to the first two components- $8.0 \%$. Finally, the fourth factor explains $6 \%$ of total variance and is related to positive environmental (policy-related and personal) attitudes.

In the next step, First-order factor analysis was deployed in order to determine the relationship between latent dimensions, as well as the greatest contributors among manifest variables, for each factor. The specified model is presented in Figure 1.

When it comes to the fit of the model, parameters chi-square statistic $\left(\chi^{2}\right)$, ratio $\chi^{2} / \mathrm{df}$, CFI, TLI, and RMSEA were taken into consideration for evaluating the model. The value of the chi-square statistic $\left(\chi^{2}\right)$, with 146 degrees of freedom (df) is $\chi^{2}=4881.999$, with significance value of $p=0.000$ and a ratio $\chi^{2} / \mathrm{df}=33.438$. As values for CFI and TLI should be 0.90 or higher, while values for RMSEA should be less than 0.05 , we can conclude that the tested model does not show a good fit $(\mathrm{CFI}=0.837$, TLI $=0.788$, RMSEA $=0.080$ ). However, it should be noted that this can be expected for the sample size of $n=5026$. The chi-square significance test is dependent on sample size and nearly always rejects the models based on large sample size [104]. In addition, it should be pointed out that Chi square value is affected by the size of the correlations in the model: the larger the correlations, the poorer the fit [105]. The chi square to $\mathrm{df}$ ratio or $\chi^{2} / \mathrm{df}$ has been in use for a long time in different types of studies. A problem with this fit index is that there is no universally agreed upon standard as to what is a good and a bad model fit. Note, however, that two currently very popular fit indices, TLI and RMSEA, are largely based on this old-fashioned ratio. 


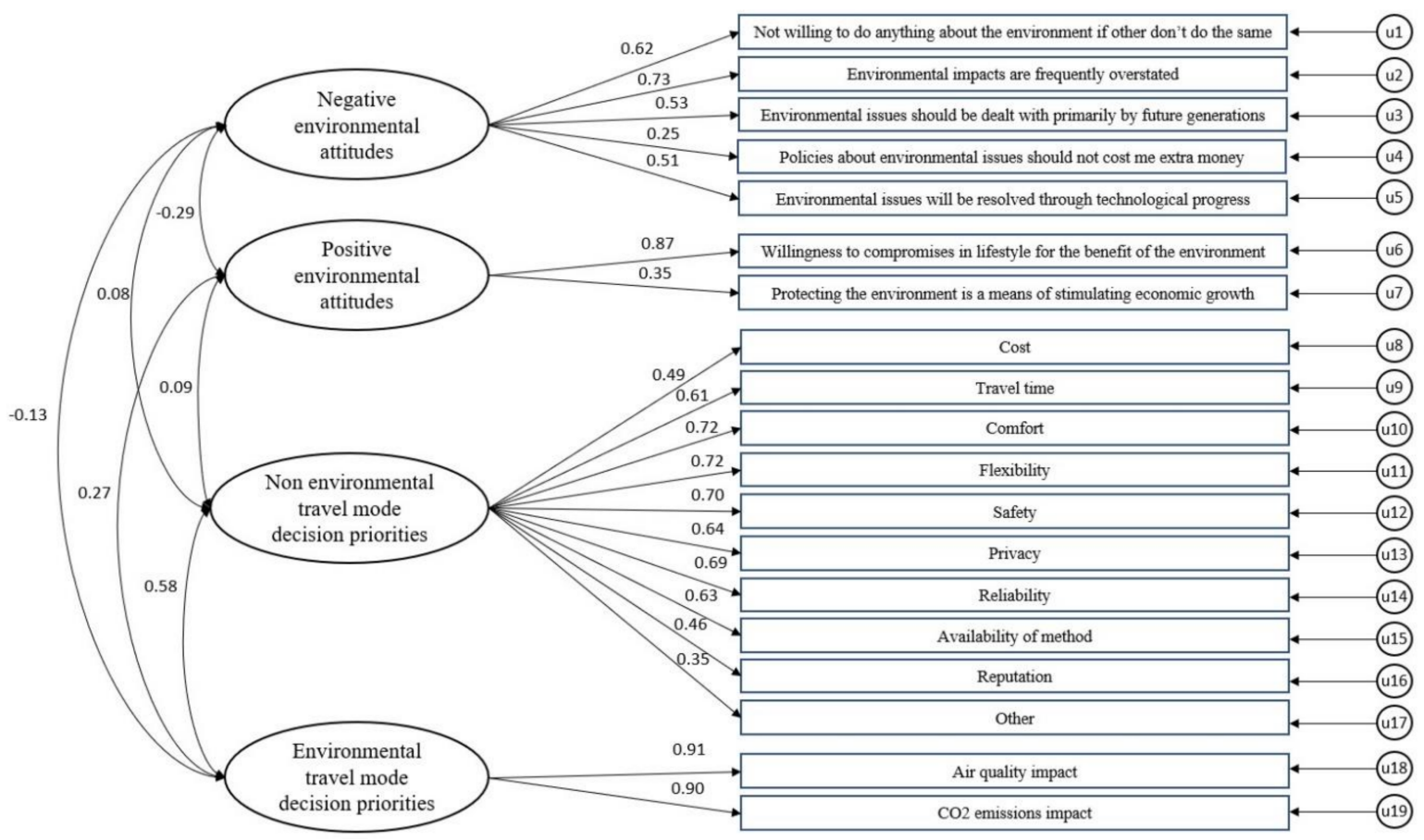

Figure 1. The first order factor model with specified correlations and standardized regression coefficients.

All specified latent dimensions show significant correlation with each other. The greatest positive correlation is between environmental travel mode decision priorities and non-environmental travel mode decision priorities $(\mathrm{r}=0.583, p=0.001)$. The second greatest positive correlation is between positive environmental (policy-related and personal) attitudes and environmental travel mode decision priorities $(\mathrm{r}=0.271, p=0.001)$. On the other hand, two negative correlations are detected, between negative and positive environmental (policy-related and personal) attitudes $(\mathrm{r}=-0.286, p=0.001)$ and negative environmental (policy-related and personal) attitudes and environmental travel mode decision priorities $(\mathrm{r}=-0.129, p=0.001)$. Correlations between factors are represented in Table 4 .

Table 4. Attitudes of travelers related to environment.

\begin{tabular}{|c|c|c|c|c|c|}
\hline & $n$ & Minimum & Maximum & Average & Std. Deviation \\
\hline $\begin{array}{l}\text { I am not willing to do anything about } \\
\text { the environment if others don't do } \\
\text { the same }\end{array}$ & 4791 & 1 & 4 & 1.96 & 0.866 \\
\hline $\begin{array}{c}\text { Environmental impacts are } \\
\text { frequently overstated }\end{array}$ & 4675 & 1 & 4 & 2.21 & 0.908 \\
\hline $\begin{array}{l}\text { Environmental issues should be dealt } \\
\text { with primarily by future generations }\end{array}$ & 4827 & 1 & 4 & 2.16 & 0.951 \\
\hline $\begin{array}{l}\text { I am willing to make compromises in } \\
\text { my current lifestyle for the benefit of } \\
\text { the environment }\end{array}$ & 4731 & 1 & 4 & 3.01 & 0.736 \\
\hline $\begin{array}{l}\text { Policies introduced by the government } \\
\text { to address environmental issues should } \\
\text { not cost me extra money }\end{array}$ & 4686 & 1 & 4 & 3.09 & 0.827 \\
\hline $\begin{array}{c}\text { Environmental issues will be resolved } \\
\text { in any case through } \\
\text { technological progress }\end{array}$ & 4299 & 1 & 4 & 2.50 & 0.857 \\
\hline $\begin{array}{l}\text { Protecting the environment is a means } \\
\text { of stimulating economic growth }\end{array}$ & 4098 & 1 & 4 & 2.96 & 0.740 \\
\hline
\end{tabular}


The last two research aims were to explore determinants of environmental attitudes and travel mode decision priorities. All manifest variables were significantly contributing to the explanation of its latent dimensions. The standardized regression coefficients of the model are shown in Table 5 . When it comes to negative environmental attitudes, statements with the highest loading on this factor are attitude that environmental impact is overstated $(b=0.726)$ and lack of willingness to do anything about environment if others don't do the same $(b=0.621)$.

Table 5. Correlations of the first-order factor model, presented in Figure 1.

\begin{tabular}{|c|c|c|c|c|c|c|}
\hline & & & St. Est. & S.E. & C.R. & $p$ \\
\hline $\begin{array}{l}\text { Environmental } \\
\text { travel mode } \\
\text { dec. pri. }\end{array}$ & $<->$ & $\begin{array}{l}\text { Non-environm. } \\
\text { travel mode } \\
\text { dec. pri }\end{array}$ & 0.583 & 0.011 & 23.901 & 0.001 \\
\hline $\begin{array}{l}\text { Environmental } \\
\text { travel mode } \\
\text { dec. pri. }\end{array}$ & $<->$ & $\begin{array}{l}\text { Positive } \\
\text { environm. } \\
\text { Attitudes }\end{array}$ & 0.271 & 0.014 & 14.833 & 0.001 \\
\hline $\begin{array}{l}\text { Positive en- } \\
\text { vironmental } \\
\text { attitudes }\end{array}$ & $<->$ & $\begin{array}{l}\text { Non-environm. } \\
\text { travel mode } \\
\text { dec. pri. }\end{array}$ & 0.092 & 0.008 & 5.057 & 0.001 \\
\hline $\begin{array}{l}\text { Negative en- } \\
\text { vironmental } \\
\text { attitudes }\end{array}$ & $<->$ & $\begin{array}{l}\text { Non-environm. } \\
\text { travel mode } \\
\text { dec. pri. }\end{array}$ & 0.077 & 0.006 & 4.167 & 0.001 \\
\hline $\begin{array}{l}\text { Environmental } \\
\text { travel mode } \\
\text { dec. pri. }\end{array}$ & $<->$ & $\begin{array}{l}\text { Negative } \\
\text { environm. } \\
\text { Attitudes }\end{array}$ & -0.129 & 0.01 & -7.005 & 0.001 \\
\hline $\begin{array}{l}\text { Negative en- } \\
\text { vironmental } \\
\text { attitudes }\end{array}$ & $<->$ & $\begin{array}{l}\text { Positive } \\
\text { environm. } \\
\text { Attitudes }\end{array}$ & -0.286 & 0.011 & -13.48 & 0.001 \\
\hline
\end{tabular}

Willingness to compromise in lifestyle for the benefit of the environment is the greatest determinant for positive environmental attitude $(b=0.866)$, while air quality $(\mathrm{b}=0.912)$ and $\mathrm{CO}_{2}$ emissions $(\mathrm{b}=0.904)$ are equally impacting environmental travel mode decision priorities.

Finally, in Table 6, the total variance of non-environmental travel preference is presented. It is mostly contributed by comfort $(b=0.721)$, flexibility $(b=0.722)$, safety $(b=0.704)$ and reliability $(b=0.690)$.

Table 6. Regression weights of the first-order factor model presented in Figure 1.

\begin{tabular}{|c|c|c|c|c|c|c|}
\hline & & & St. Est. & S.E. & C.R. & $p$ \\
\hline Air quality impact & $<-$ & $\begin{array}{l}\text { Environm. travel mode } \\
\text { dec. pri. }\end{array}$ & 0.912 & & & 0.001 \\
\hline $\mathrm{CO}_{2}$ emissions impact & $<-$ & $\begin{array}{l}\text { Environm. travel mode } \\
\text { dec. pri. }\end{array}$ & 0.904 & 0.016 & 61.667 & 0.001 \\
\hline $\begin{array}{l}\text { I am willing to make } \\
\text { compromises in my } \\
\text { current lifestyle for the } \\
\text { benefit of ... }\end{array}$ & $<-$ & $\begin{array}{l}\text { Positive environm. } \\
\text { attitudes }\end{array}$ & 0.866 & & & 0.001 \\
\hline $\begin{array}{l}\text { Environmental impacts are } \\
\text { frequently overstated }\end{array}$ & $<-$ & $\begin{array}{l}\text { Negative environm. } \\
\text { attitudes }\end{array}$ & 0.726 & 0.039 & 29.637 & 0.001 \\
\hline Flexibility & $<-$ & $\begin{array}{l}\text { Non-environm. travel } \\
\text { mode dec. pri. }\end{array}$ & 0.722 & 0.046 & 31.904 & 0.001 \\
\hline Comfort & $<-$ & $\begin{array}{l}\text { Non-environm. travel } \\
\text { mode dec. pri. }\end{array}$ & 0.721 & 0.046 & 31.935 & 0.001 \\
\hline
\end{tabular}


Table 6. Cont.

\begin{tabular}{|c|c|c|c|c|c|c|}
\hline & & & St. Est. & S.E. & C.R. & $p$ \\
\hline Safety & $<-$ & $\begin{array}{l}\text { Non-environm. travel } \\
\text { mode dec. pri. }\end{array}$ & 0.704 & 0.046 & 31.575 & 0.001 \\
\hline Reliability & $<-$ & $\begin{array}{l}\text { Non-environm. travel } \\
\text { mode dec. pri. }\end{array}$ & 0.69 & 0.045 & 31.272 & 0.001 \\
\hline Privacy & $<-$ & $\begin{array}{l}\text { Non-environm. travel } \\
\text { mode dec. pri. }\end{array}$ & 0.638 & 0.044 & 30.009 & 0.001 \\
\hline Availability of method & $<-$ & $\begin{array}{l}\text { Non-environm. travel } \\
\text { mode dec. pri. }\end{array}$ & 0.626 & 0.043 & 29.799 & 0.001 \\
\hline $\begin{array}{l}\text { I am not willing to do } \\
\text { anything about the } \\
\text { environment if others ... }\end{array}$ & $<-$ & $\begin{array}{l}\text { Negative environm. } \\
\text { attitudes }\end{array}$ & 0.621 & & & 0.001 \\
\hline Travel time & $<-$ & $\begin{array}{l}\text { Non-environm. travel } \\
\text { mode dec. pri. }\end{array}$ & 0.605 & 0.042 & 29.29 & 0.001 \\
\hline $\begin{array}{l}\text { Environmental issues } \\
\text { should be dealt with } \\
\text { primarily by future... }\end{array}$ & $<-$ & $\begin{array}{l}\text { Negative environm. } \\
\text { attitudes }\end{array}$ & 0.529 & 0.032 & 26.358 & 0.001 \\
\hline $\begin{array}{l}\text { Environmental issues will } \\
\text { be resolved in any case ... }\end{array}$ & $<-$ & $\begin{array}{c}\text { Negative environm. } \\
\text { attitudes }\end{array}$ & 0.514 & 0.033 & 25.042 & 0.001 \\
\hline Cost & $<-$ & $\begin{array}{l}\text { Non-environm. travel } \\
\text { mode dec. pri. }\end{array}$ & 0.487 & & & 0.001 \\
\hline Reputation & $<-$ & $\begin{array}{l}\text { Non-environm. travel } \\
\text { mode dec. pri. }\end{array}$ & 0.459 & 0.039 & 24.383 & 0.001 \\
\hline Other & $<-$ & $\begin{array}{l}\text { Non-environm. travel } \\
\text { mode dec. pri. }\end{array}$ & 0.355 & 0.072 & 9.791 & 0.001 \\
\hline $\begin{array}{l}\text { Protecting the } \\
\text { environment is a means of } \\
\text { stimulating economic ... }\end{array}$ & $<-$ & $\begin{array}{l}\text { Positive environm. } \\
\text { attitudes }\end{array}$ & 0.352 & 0.051 & 7.906 & 0.001 \\
\hline $\begin{array}{l}\text { Policies introduced } \\
\ldots \text {. should not cost me } \\
\text { extra money }\end{array}$ & $<-$ & $\begin{array}{l}\text { Negative environm. } \\
\text { attitudes }\end{array}$ & 0.253 & 0.029 & 14.071 & 0.001 \\
\hline
\end{tabular}

St. Est.-Standardized Estimate; S.E.-approximate standard error; C.R. critical ratio.

The second-order factor analysis was conducted in order to determine if specified latent variables (Negative environmental attitudes, positive environmental attitudes, environmental travel mode decision priorities, non-environmental travel mode decision priorities) are antecedents of higher (second) order latent variable-Sustainable travel decision-making. In the second-order factor analysis variables "Environmental issues should be primarily dealt by future generations", "Cost", "Privacy", "Other" and "Reputation" were excluded from the analysis since they were highly correlated with other variables that are explaining the same latent variable. Specified model is presented in Figure 2. 


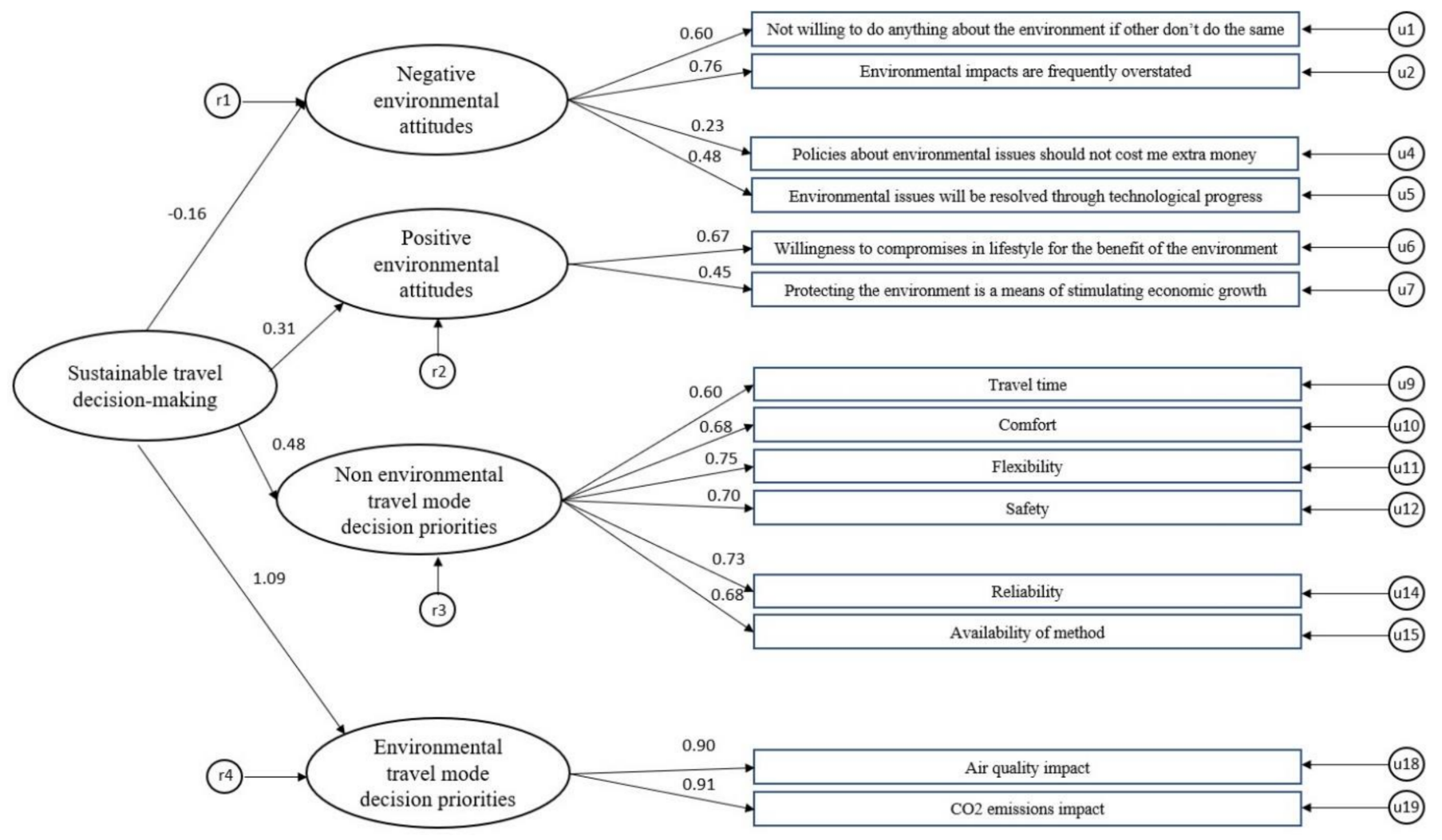

Figure 2. The second order factor model with specified standardized regression coefficient.

When it comes to the fit of the model, the value of the chi-square statistic $\left(\chi^{2}\right)$, with 73 degrees of freedom (df) is $\chi^{2}=2083.602$, with significance value of $p=0.000$ and a ratio $\chi^{2} / \mathrm{df}=28.542$. Values of CFI, TLI and RMSEA improved compared to the values in the first-order model, so we can conclude that the second-order factor model is better in explaining variance between variables $(\mathrm{CFI}=0.905, \mathrm{TLI}=0.864$, $\mathrm{RMSEA}=0.074)$, compared to $(\mathrm{CFI}=0.837$, TLI $=0.788$, RMSEA $=0.080)$ in the first-order model. The CFI value of the second-order model is above the threshold for goodness of fit and therefore the most important fit index points to a model with good fit. TLI is under the threshold of 0.95, therefore not pointing to a model with good fit, while RMSEA is above 0.05 , therefore also not satisfying the badness of fit index. It should be noted though that both TLI and RMSEA are sensitive to large sample sizes, and nearly always reject the models based on large sample sizes [104].

As presented in Table 7, all four first-order latent factors significantly contribute to the explanation of the second-order latent factor-Sustainable travel decision making. Nonenvironmental travel mode decision priorities are the greatest determinant of sustainable travel decision making $(b=0.480)$, while negative environmental attitudes are contributing the least to the variance of the second-order factor $(b=-0.160)$. 
Table 7. Regression weights of the second-order factor model in Figure 2.

\begin{tabular}{|c|c|c|c|c|c|c|}
\hline & & & $\begin{array}{l}\text { Standardized } \\
\text { Estimate }\end{array}$ & S.E. & C.R. & $p$ \\
\hline $\begin{array}{l}\text { Negative } \\
\text { environm. } \\
\text { Attitudes }\end{array}$ & $<-$ & $\begin{array}{c}\text { Sustainable } \\
\text { travel } \\
\text { decision } \\
\text { making }\end{array}$ & -0.160 & 0.015 & -6.494 & 0.001 \\
\hline $\begin{array}{l}\text { Positive } \\
\text { environm. } \\
\text { Attitudes }\end{array}$ & $<-$ & $\begin{array}{c}\text { Sustainable } \\
\text { travel } \\
\text { decision } \\
\text { making }\end{array}$ & 0.311 & 0.027 & 7.857 & 0.001 \\
\hline $\begin{array}{l}\text { Non envi- } \\
\text { ronmental } \\
\text { travel } \\
\text { mode dec. } \\
\text { pri. }\end{array}$ & $<-$ & $\begin{array}{c}\text { Sustainable } \\
\text { travel } \\
\text { decision } \\
\text { making }\end{array}$ & 0.480 & 0.033 & 8.836 & 0.001 \\
\hline $\begin{array}{l}\text { Environmental } \\
\text { travel } \\
\text { mode dec. } \\
\text { pri. }\end{array}$ & $<-$ & $\begin{array}{c}\text { Sustainable } \\
\text { travel } \\
\text { decision } \\
\text { making }\end{array}$ & 1.085 & & & 0.001 \\
\hline
\end{tabular}

\section{Discussion, Future Research Direction and Limitations}

Transportation accounts for the majority of greenhouse emissions among all tourist activities [9]. These findings point to the central importance of understanding sustainable travel decision-making, both regarding theoretical implications this might have as well as practical implications.

The research uncovers the processes behind travelers' choices of sustainable and environmentally sound offers, thereby continuing the early research by Stern [8]. However, the research goes further to also provide the evidence on the processes behind choosing unsustainable offers, thereby presenting the complexities of sustainable travel decisionmaking. In this sense, the results explain the cognitive dissonance created by conflicting attitudes and priorities in sustainable travel decision-making. This issue has been identified by Hares, Dickinson and Wilkes [4] deploying a qualitative methodology. Present research provides further quantitative evidence in this research stream by including a significantly larger population in the research, thereby increasing the reliability of results as well as generalizability. The results also contribute to literature on attitude-behavior discrepancies in sustainable travel and tourism [17], by contributing to a better understanding of this phenomenon in the European context. European citizens are generally willing to make sacrifices in their current lifestyles, but are not willing pay more and they also expect the technological advancement to resolve these problems. In this sense, air travel in particular suffers from a strong attitude-behavior inconsistency of its travelers, leaving travelers with the need to reconcile their environmental attitudes with the necessity of air travel [77]. Regarding the literature on negative environmental attitudes [89,92], this study has uncovered that the most important negative environmental attitudes are: (a) that environmental impacts are overstated and (b) unwillingness to do anything about the environment if others don't do the same, as well as (c) environmental issues should be dealt with primarily by future generations. The second-order model has confirmed that costs, privacy and reputation belong to contextual factors, while travel time, comfort, flexibility, safety, reliability and availability of method belong to factors related to lifestyle change, as previously defined in the literature.

The study deals with the role of attitudes and travel mode decision priorities in sustainable travel decision-making, thereby bridging the gap in literature regarding sustainable decision-making. Although attitudes have long been researched in social sciences inside TRA and TPB and more recently in sustainable tourism, little has been done to model 
the impact of attitudes on travel decision making $[55,56,106]$. This research gap is even more pronounced in the subfield of sustainable travel decision-making. Both TRA and TPB posit that the attitudes influence the behavior through behavioral intentions, but the impact of attitudes on decision-making has not been well researched. The PCA results demonstrated the existence of positive and negative environmental attitudes as separate factors, as well as pro-environmental and non-environmental travel priorities in sustainable travel decision-making. The first-order and second-order model investigate the impact of the two identified attitudes groups as well as travel mode priorities on sustainable travel decision-making.

The results are of relevance for managers in the travel and tourism industry as well as the passenger transport industry and to a lesser extent the mobility solutions industry. Managers in these industries need to tackle the issues of sustainability (pro-environmental attitudes and behavior) and non-sustainability (negative attitudes towards environment and non-sustainable behavior) on a daily basis. They are often confronted with travelers' dilemmas, incomprehension, confusion and even denial regarding sustainable travel decision-making. The development and management of travel products and services on the market should provide clear answers as to how the offer measures up regarding the carbon footprint as well as air quality. Possible alternatives could be considered to address these two issues while trying not to jeopardize flexibility, reliability and safety. The importance of positive attitudes like the willingness to compromise own lifestyle for the benefit of the environment, should be taken into account in travel offer management. On the other hand, the existence of negative environmental attitudes should be acknowledged and therefore the description of environmental impacts should not be overstated. In addition, if a person is not willing to make personal sacrifices for the environment, role-modelling and communicating about exemplary customers should be done. This could create a sense of belonging and "others already do it" effect among customers with negative environmental attitudes.

One possible limitation of the study is that the data have been collected inside a larger, rather extensive research questionnaire, therefore making the answers susceptible to Common Method Variance (CMV) bias, through transient mood states, such as boredom and fatigue, as observed by [107]. In order to counteract this potential problem and diminish the impact of CMV, neither of the researched items have been placed at the end or near the end of the questionnaire. In addition, Likert scales with different endpoints (1-7 and 1-5) have been used in questionnaire, as suggested by [108]. Different scales have been accounted for in later analysis by using normalized scores instead of original values. Additionally, positive and negative attitudes as well as environmental and nonenvironmental attitudes have been placed in a mixed order. In order to further address CMV, two ex-post statistical tests have been deployed on the data. The first one is the Harman's Single-Factor Test, and the second one is the common factor method, both proposed in previous literature $[109,110]$. For Harman's test, a PCA has been conducted with only one factor and no rotation, where Factor 1 loaded at 6.41 level, explaining 33.75\% of the variance. As this value is under $50 \%$ it is said to be satisfactory, therefore pointing to the absence of CMV bias. For common factor method, a common latent variable has been introduced in the AMOS model, where all paths to the common latent variable have been set to be equal. It resulted in all paths to the common latent variable being 0.18 - when squared it returns 0.03 , pointing to $3 \%$ of common variance, which is under the threshold value of $50 \%$. Therefore, we can conclude that it is highly unlikely that the answers to the questionnaire suffer from CMV bias.

Another limitation of the study is that it did not use validated scales for preparing this survey instrument, which can hinder future replication of this research.

\section{Conclusions}

Future efforts for sustainable mobility and travel solutions need to prioritize wide availability, reliability, safety and flexibility as non-environmental travel mode decision 
priorities, especially for commuting, but also for business travel or leisure travel. According to Boniface and Cooper [111], all these activities are a part of the travel and tourism continuum. Environmentally related travel mode decision priorities, like air quality impact and $\mathrm{CO}_{2}$ emissions are of secondary importance for travel mode decision making, but also represent the most important antecedent of sustainable travel decision-making, presented in the second-order model. These issues should be considered in parallel with the issues of consumer reputation and moral licensing, as well as denial, critique and other negative attitudes towards the environment. The most important negative environmental attitude identified is that environmental impacts are overstated as well as unwillingness to do anything about the environment if others do not do the same. On the other side, willingness to compromise own lifestyle for the benefit of the environment seems to be the greatest determinant of positive environmental attitude. Generally, European consumers and citizens are willing to make compromises in their current lifestyle, but are expecting significant financial commitment from product and service providers for deploying advanced technology for solving environmentally unsound practices. Therefore, support of future environmental policies depends on just and fair financing mechanisms, e.g., polluter pays principle or public-private partnerships in developing innovative technologies.

Understanding the travel behavior of travelers, commuters and tourists is a basis for validating and ultimately implementing innovative environmental technologies, which should spearhead the transitions towards sustainable travel and tourism. The current COVID-19 crisis has demonstrated the importance of new environmental factors in travel decision making, which haven't been included in this study. The present crisis has also taught us how quickly environmental factors, which are seemingly of secondary importance for travel decision-making, can quickly become a matter of urgent and utmost importance for each and every travel decision around the globe. As a consequence of theCOVID-19 crisis, the tourist sector (together with its global value-chain) has been directly affected in the first wave of crisis. Having in mind that tourism accounted for $7 \%$ of global trade in 2019 and that it provides one in ten jobs, the sudden fall in tourism has a wider impact not only on economic, but also on social and environmental aspects of the global society. The crisis will hit all sectors associated with travel and tourism, such as labor-intensive accommodation, food service industries and small businesses where especially vulnerable groups, such as woman, youth and workers are employed. A dramatic reduction in revenues in travel and tourism industry will cut off funding for the environment (e.g., for reduced number of tourists and staff, funds for biodiversity conservation could also be reduced) while further consistent revenue pressure can shift environmental issues from the priority list. The behavior of tourists in relation to environmental issues which are not related to health aspects $\left(\mathrm{CO}_{2}\right.$, air quality) will probably temporarily be in the second row of priorities, having in mind the acuteness of the present crisis for travelers and potential travelers around the globe.

Important lessons for the theory of sustainability-related behavior are manyfold. The most important contribution is that the second-order factor model represents in detail the attitude-behavior gap in sustainable tourism, which has been identified by previous literature [19] and introduces a novel latent construct called sustainable travel decisionmaking in order to explain this gap by presenting attitudes and travel mode priorities as it's antecedents. Regarding this newly created latent construct, negative attitudes towards the environment are the least important antecedent of European travelers' sustainable travel decision-making. On the other hand, environmental travel mode decision priorities (air quality impact and $\mathrm{CO}_{2}$ emission impact) are the most important antecedent of sustainable travel decision making in Europe, followed by non-environmental travel mode decision priorities (flexibility, comfort, safety, reliability, availability of method, travel time).

In order to advance sustainability efforts, the tourist industry should develop strategies for including additional risk management dimensions, especially regarding environmental aspects. The COVID-19 crisis has opened space for reshaping the travel and tourism system in accordance with sustainability principles. In the forthcoming period, there will 
be challenges regarding how to balance between cost pressure due to business losses and implementation of environmentally friendly commitments. Moving ahead, sustainable travel and tourism will need to be more resource efficient and carbon-neutral. This transition and transformation need to take into account environmentally friendly consumer behavior which can only be reshaped through adequate education, innovation and further investment into research and development.

Author Contributions: Conceptualization, I.P. and T.M.N.; methodology, T.M.N. and I.P.; software, I.P.; validation, T.M.N., S.P.P.; formal analysis, I.P.; investigation, S.F.; resources, S.F.; data curation, I.P.; writing—original draft preparation, I.P.; writing—review and editing, T.M.N., S.P.P. and S.F.; supervision, T.M.N.; project administration, S.F.; funding acquisition, S.F. All authors have read and agreed to the published version of the manuscript.

Funding: This research was partially funded by ENABLE.EU project (Ref No. 727524) of the H2020 program of the European Commission, as well as supported by the Ministry of Education, Science and Technological Development of the Republic of Serbia and supported by Enterprise Europe Network.

Institutional Review Board Statement: Not applicable.

Informed Consent Statement: Not applicable.

Data Availability Statement: Not applicable.

Conflicts of Interest: The authors declare no conflict of interest. The funders had no role in the design of the study; in the collection, analyses, or interpretation of data; in the writing of the manuscript, or in the decision to publish the results.

\section{Appendix A}

Table 1. How much do you agree with the following statements?

\begin{tabular}{|c|c|c|c|c|c|c|}
\hline & & Strongly Disagree & Disagree & Agree & Strongly Agree & Don't Know \\
\hline NegAtt1 & $\begin{array}{l}\text { I am not willing to do } \\
\text { anything about the } \\
\text { environment if others } \\
\text { don't do the same }\end{array}$ & 1 & 2 & 3 & 4 & 99 \\
\hline NegAtt2 & $\begin{array}{l}\text { Environmental impacts } \\
\text { are frequently overstated }\end{array}$ & 1 & 2 & 3 & 4 & 99 \\
\hline NegAtt3 & $\begin{array}{c}\text { Environmental issues } \\
\text { should be dealt with } \\
\text { primarily by future } \\
\text { generations }\end{array}$ & 1 & 2 & 3 & 4 & 99 \\
\hline PosAtt1 & $\begin{array}{l}\text { I am willing to make } \\
\text { compromises in my } \\
\text { current lifestyle for the } \\
\text { benefit of the } \\
\text { environment }\end{array}$ & 1 & 2 & 3 & 4 & 99 \\
\hline & $\begin{array}{l}\text { Policies introduced by } \\
\text { the government to }\end{array}$ & & & & & \\
\hline NegAtt 4 & $\begin{array}{l}\text { address environmental } \\
\text { issues should not cost me } \\
\text { extra money }\end{array}$ & 1 & 2 & 3 & 4 & 99 \\
\hline NegAtt5 & $\begin{array}{c}\text { Environmental issues } \\
\text { will be resolved in any } \\
\text { case through } \\
\text { technological progress }\end{array}$ & 1 & 2 & 3 & 4 & 99 \\
\hline PosAtt2 & $\begin{array}{l}\text { Protecting the } \\
\text { environment is a means } \\
\text { of stimulating economic } \\
\text { growth }\end{array}$ & 1 & 2 & 3 & 4 & 99 \\
\hline
\end{tabular}


Table 2. What importance do the following factors have in your decision between different methods of travel?

\begin{tabular}{|c|c|c|c|c|c|c|c|}
\hline & & $\begin{array}{l}\text { Not at All } \\
\text { Important }\end{array}$ & 2 & 3 & 4 & $\begin{array}{c}\text { Very } \\
\text { Important }\end{array}$ & Don't Know \\
\hline NonEnv1 & Cost & 1 & 2 & 3 & 4 & 5 & 99 \\
\hline NonEnv2 & Travel time & 1 & 2 & 3 & 4 & 5 & 99 \\
\hline NonEnv3 & Comfort & 1 & 2 & 3 & 4 & 5 & 99 \\
\hline NonEnv4 & Flexibility & 1 & 2 & 3 & 4 & 5 & 99 \\
\hline NonEnv5 & Safety & 1 & 2 & 3 & 4 & 5 & 99 \\
\hline NonEnv6 & Privacy & 1 & 2 & 3 & 4 & 5 & 99 \\
\hline Env1 & $\begin{array}{c}\text { Air quality } \\
\text { impact } \\
\mathrm{CO}_{2}\end{array}$ & 1 & 2 & 3 & 4 & 5 & 99 \\
\hline Env2 & $\begin{array}{l}\text { emissions } \\
\text { impact }\end{array}$ & 1 & 2 & 3 & 4 & 5 & 99 \\
\hline NonEnv7 & Reliability & 1 & 2 & 3 & 4 & 5 & 99 \\
\hline NonEnv8 & Availability & 1 & 2 & 3 & 4 & 5 & 99 \\
\hline NonEnv9 & Reputation & 1 & 2 & 3 & 4 & 5 & 99 \\
\hline Other & Other & 1 & 2 & 3 & 4 & 5 & 99 \\
\hline
\end{tabular}

Table 3. Previous use of items.

\begin{tabular}{|c|c|c|c|c|c|c|}
\hline & $\begin{array}{l}\text { Research } \\
\text { Approach }\end{array}$ & Source & $\begin{array}{l}\text { Research } \\
\text { Approach }\end{array}$ & Source & $\begin{array}{l}\text { Research } \\
\text { Approach }\end{array}$ & Source \\
\hline Item & $\begin{array}{l}\text { Psycholog. } \\
\text { Basis of Pro- } \\
\text { Environmental } \\
\text { Behavior }\end{array}$ & [92] & $\begin{array}{l}\text { Denying and } \\
\text { Opposing } \\
\text { Sustainability } \\
\text { Problems }\end{array}$ & [89] & $\begin{array}{l}\text { Air Travel } \\
\text { Attitudes }\end{array}$ & [77] \\
\hline $\begin{array}{l}\text { I am not willing to do } \\
\text { anything about the } \\
\text { environment if others don't do } \\
\text { the same }\end{array}$ & \multicolumn{2}{|c|}{$\begin{array}{l}\text { Personal or joint ascription of } \\
\text { responsibility }\end{array}$} & \multicolumn{2}{|c|}{$\begin{array}{l}\text { Responsibility minimization } \\
\text { by comparing to others; } \\
\text { socially organized denial }\end{array}$} & \multicolumn{2}{|c|}{$\begin{array}{l}\text { Individuals are powerless to } \\
\text { change anything by themselves }\end{array}$} \\
\hline $\begin{array}{l}\text { Environmental impacts are } \\
\text { frequently overstated }\end{array}$ & & & \multicolumn{2}{|c|}{$\begin{array}{c}\text { Defense mechanism of } \\
\text { denying uncomfortable truth }\end{array}$} & \multicolumn{2}{|c|}{$\begin{array}{l}\text { Doubt in the adequate level of } \\
\text { taxes for environmental causes } \\
\text { (just one more way to tax) }\end{array}$} \\
\hline $\begin{array}{l}\text { Environmental issues should } \\
\text { be dealt with primarily by } \\
\text { future generations }\end{array}$ & & & $\begin{array}{r}\text { Minimization of } \\
\text { pointing to otl } \\
\text { should be more }\end{array}$ & $\begin{array}{l}\text { wn acts by } \\
\text { s which } \\
\text { sponsible }\end{array}$ & $\begin{array}{r}\text { We should enj } \\
\text { practices whil } \\
\text { will get me }\end{array}$ & $\begin{array}{l}\text { ustainable } \\
\text { an, as they } \\
\text { gensive }\end{array}$ \\
\hline $\begin{array}{l}\text { I am willing to make } \\
\text { compromises in my current } \\
\text { lifestyle for the benefit of the } \\
\text { environment }\end{array}$ & \multirow{2}{*}{\multicolumn{2}{|c|}{$\begin{array}{l}\text { Willingness to sacrifice } \\
\text { through paying more and } \\
\text { getting a product/service of } \\
\text { lower value }\end{array}$}} & \multirow{2}{*}{\multicolumn{2}{|c|}{$\begin{array}{c}\text { Focus on individual actions } \\
\text { that should lead to a } \\
\text { collectively more sustainable } \\
\text { outcome }\end{array}$}} & \multirow{2}{*}{\multicolumn{2}{|c|}{$\begin{array}{l}\text { Denial of environmental } \\
\text { problems and even dismissal of } \\
\text { government intentions by } \\
\text { opposing additional taxes of } \\
\text { personal flight quotas }\end{array}$}} \\
\hline $\begin{array}{l}\text { Policies introduced by the } \\
\text { government to address } \\
\text { environmental issues should } \\
\text { not cost me extra money }\end{array}$ & & & & & & \\
\hline $\begin{array}{l}\text { Environmental issues will be } \\
\text { resolved in any case through } \\
\text { technological progress }\end{array}$ & & & \multicolumn{2}{|c|}{$\begin{array}{l}\text { Minimization of own acts by } \\
\text { pointing to new technology }\end{array}$} & $\begin{array}{r}\text { New techno } \\
\text { solu } \\
\text { environme }\end{array}$ & $\begin{array}{l}\text { s a likely } \\
\text { roblems }\end{array}$ \\
\hline $\begin{array}{l}\text { Protecting the environment is } \\
\text { a means of stimulating } \\
\text { economic growth }\end{array}$ & & & \multicolumn{2}{|c|}{$\begin{array}{l}\text { Moral licensing of } \\
\text { environmental technology as } \\
\text { contributing to higher cause }\end{array}$} & \multicolumn{2}{|c|}{$\begin{array}{c}\text { Moral licensing of } \\
\text { unsustainable technology as } \\
\text { contributing to economic } \\
\text { development }\end{array}$} \\
\hline
\end{tabular}


Table 4. Previous use of items.

\begin{tabular}{cc}
\hline Item & Source \\
\hline Cost & {$[4]$} \\
Travel time & {$[4]$} \\
Comfort & {$[97]$} \\
Flexibility & {$[99]$} \\
Safety & {$[62]$} \\
Privacy & {$[97]$} \\
Air quality impact & {$[23]$} \\
$\mathrm{CO}_{2}$ emissions impact & {$[80]$} \\
Reliability & {$[101]$} \\
Availability & {$[4]$} \\
Reputation & {$[102]$} \\
Other & {$[4]$} \\
\hline
\end{tabular}

\section{References}

1. Jacobsen, J.K.S.; Iversen, N.M.; Hem, L.E. Hotspot crowding and over-tourism: Antecedents of destination attractiveness. Ann. Tour. Res. 2019, 76, 53-66. [CrossRef]

2. Kim, H.-R.; Yoon, S.-Y. How to Help Crowded Destinations: Tourist Anger vs. Sympathy and Role of Destination Social Responsibility. Sustainability 2020, 12, 2358. [CrossRef]

3. Zhang, A.; Zhong, L.; Xu, Y.; Wang, H.; Dang, L. Tourists' Perception of Haze Pollution and the Potential Impacts on Travel: Reshaping the Features of Tourism Seasonality in Beijing, China. Sustainability 2015, 7, 2397-2414. [CrossRef]

4. Hares, A.; Dickinson, J.; Wilkes, K. Climate change and the air travel decisions of UK tourists. J. Transp. Geogr. 2010, 18, 466-473. [CrossRef]

5. Gössling, S. Global environmental consequences of tourism. Glob. Environ. Chang. 2002, 12, 283-302. [CrossRef]

6. Vujko, A.; Gajic, T. Opportunities for tourism development and cooperation in the region by improving the quality of tourism services-the ‘Danube Cycle Route'case study. Econ. Res.-Ekon. Istraživanja 2014, 27, 847-860. [CrossRef]

7. Etminani-Ghasrodashti, R.; Paydar, M.; Ardeshiri, A. Recreational cycling in a coastal city: Investigating lifestyle, attitudes and built environment in cycling behavior. Sustain. Cities Soc. 2018, 39, 241-251. [CrossRef]

8. Stern, P.C. New environmental theories: Toward a coherent theory of environmentally significant behavior. J. Soc. Issues $\mathbf{2 0 0 0 , 5 6 ,}$ 407-424. [CrossRef]

9. UNEP Environmental Impact Assessment and Strategic Environmental Assessment: Towards an Integrated Approach. Available online: https://www.unenvironment.org/resources/report/environmental-impact-assessment-and-strategic-environmentalassessment-towards (accessed on 3 February 2021).

10. Gössling, S.; Garrod, B.; Aall, C.; Hille, J.; Peeters, P. Food management in tourism: Reducing tourism's carbon 'foodprint'. Tour. Manag. 2011, 32, 534-543. [CrossRef]

11. Becken, S.; Simmons, D.G. Understanding energy consumption patterns of tourist attractions and activities in New Zealand. Tour. Manag. 2002, 23, 343-354. [CrossRef]

12. Zhang, B.; Ritchie, B.; Mair, J.; Driml, S. Is the Airline Trustworthy? The Impact of Source Credibility on Voluntary Carbon Offsetting. J. Travel Res. 2018, 58, 715-731. [CrossRef]

13. Miller, D.; Merrilees, B.; Coghlan, A. Sustainable urban tourism: Understanding and developing visitor pro-environmental behaviours. J. Sustain. Tour. 2015, 23, 26-46. [CrossRef]

14. Esparon, M.; Gyuris, E.; Stoeckl, N. Does ECO certification deliver benefits? An empirical investigation of visitors' perceptions of the importance of ECO certification's attributes and of operators' performance. J. Sustain. Tour. 2014, 22, 148-169. [CrossRef]

15. Lee, T.H.; Jan, F.-H.; Yang, C.-C. Conceptualizing and measuring environmentally responsible behaviors from the perspective of community-based tourists. Tour. Manag. 2013, 36, 454-468. [CrossRef]

16. Baca-Motes, K.; Brown, A.; Gneezy, A.; Keenan, E.A.; Nelson, L.D. Commitment and behavior change: Evidence from the field. J. Consum. Res. 2013, 39, 1070-1084. [CrossRef]

17. Juvan, E.; Dolnicar, S. Drivers of pro-environmental tourist behaviours are not universal. J. Clean. Prod. 2017, 166, 879-890. [CrossRef]

18. McKercher, B.; Prideaux, B.; Cheung, C.; Law, R. Achieving voluntary reductions in the carbon footprint of tourism and climate change. J. Sustain. Tour. 2010, 18, 297-317. [CrossRef]

19. Juvan, E.; Dolnicar, S. The attitude-behaviour gap in sustainable tourism. Ann. Tour. Res. 2014, 48, 76-95. [CrossRef]

20. Bausch, T.; Humpe, A.; Gössling, S. Does Climate Change Influence Guest Loyalty at Alpine Winter Destinations? Sustainability 2019, 11, 4233. [CrossRef]

21. Omar, H. The Development of Sustainable Cultural Heritage Tourism in Malaysia: Implication for Planning and Management. Ph.D. Thesis, Newcastle University, Newcastle Upon Tyne, UK, 2013.

22. Festinger, L. A Theory of Cognitive Dissonance; Stanford University Press: Redwood City, CA, USA, 1957. 
23. Westin, K.; Nordlund, A.; Jansson, J.; Nilsson, J. Goal Framing as a Tool for Changing People's Car Travel Behavior in Sweden. Sustainability 2020, 12, 3695. [CrossRef]

24. EC. Transport in the European Union-Current Trends and Issues; Directorate-General Mobility and Transport: Brussels, Belgium, 2019.

25. Diekmann, A.; Preisendörfer, P. Green and greenback: The behavioral effects of environmental attitudes in low-cost and high-cost situations. Ration. Soc. 2003, 15, 441-472. [CrossRef]

26. Mattar, L.; Abiad, M.G.; Chalak, A.; Diab, M.; Hassan, H. Attitudes and behaviors shaping household food waste generation: Lessons from Lebanon. J. Clean. Prod. 2018, 198, 1219-1223. [CrossRef]

27. Kim, A.K.; Airey, D.; Szivas, E. The multiple assessment of interpretation effectiveness: Promoting visitors' environmental attitudes and behavior. J. Travel Res. 2011, 50, 321-334.

28. Taylor, C.; Barber, N.; Deale, C. Environmental attitudes towards wine tourism. Int. J. Wine Res. 2010, $13,13-26$.

29. Untaru, E.; Epuran, G.; Ispas, A. A conceptual framework of consumers'pro-environmental attitudes and behaviours in the tourism context. Bull. Transilv. Univ. Bras. Econ. Sci. Ser. V 2014, 7, 85.

30. Casaló, L.V.; Escario, J.-J. Heterogeneity in the association between environmental attitudes and pro-environmental behavior: A multilevel regression approach. J. Clean. Prod. 2018, 175, 155-163. [CrossRef]

31. Lee, T.H. A Structural Model to Examine How Destination Image, Attitude, and Motivation Affect the Future Behavior of Tourists. Leis. Sci. 2009, 31, 215-236. [CrossRef]

32. López-Bonilla, J.; Reyes-Rodríguez, M.; López-Bonilla, L. The Environmental Attitudes and Behaviours of European Golf Tourists. Sustainability 2018, 10, 2214. [CrossRef]

33. Aminrad, Z.; Zakariya, S.; Hadi, A.S.; Sakari, M. Relationship between awareness, knowledge and attitudes towards environmental education among secondary school students in Malaysia. World Appl. Sci. J. 2013, 22, 1326-1333.

34. Susilo, Y.O.; Williams, K.; Lindsay, M.; Dair, C. The influence of individuals' environmental attitudes and urban design features on their travel patterns in sustainable neighborhoods in the UK. Transp. Res. Part D Transp. Environ. 2012, 17, 190-200. [CrossRef]

35. Ye, R.; Titheridge, H. Satisfaction with the commute: The role of travel mode choice, built environment and attitudes. Transp. Res. Part D Transp. Environ. 2017, 52, 535-547. [CrossRef]

36. Larson, L.R.; Whiting, J.W.; Green, G.T. Exploring the influence of outdoor recreation participation on pro-environmental behaviour in a demographically diverse population. Local Environ. 2011, 16, 67-86. [CrossRef]

37. Kil, N.; Holland, S.M.; Stein, T.V. Structural relationships between environmental attitudes, recreation motivations, and environmentally responsible behaviors. J. Outdoor Recreat. Tour. 2014, 7, 16-25. [CrossRef]

38. Larson, L.R.; Stedman, R.C.; Cooper, C.B.; Decker, D.J. Understanding the multi-dimensional structure of pro-environmental behavior. J. Environ. Psychol. 2015, 43, 112-124. [CrossRef]

39. Kang, M.; Moscardo, G. Exploring cross-cultural differences in attitudes towards responsible tourist behaviour: A comparison of Korean, British and Australian tourists. Asia Pac. J. Tour. Res. 2006, 11, 303-320. [CrossRef]

40. Hall, C.M.; Dayal, N.; Majstorović, D.; Mills, H.; Paul-Andrews, L.; Wallace, C.; Truong, V.D. Accommodation consumers and providers' attitudes, behaviours and practices for sustainability: A systematic review. Sustainability 2016, 8, 625. [CrossRef]

41. Stodolska, M. Implications of the conditioned attitude model of individual discriminatory behavior for discrimination in leisure settings. Leis. Sci. 2005, 27, 59-74. [CrossRef]

42. Gamborg, C.; Jensen, F.S. Attitudes towards recreational hunting: A quantitative survey of the general public in Denmark. J. Outdoor Recreat. Tour. 2017, 17, 20-28. [CrossRef]

43. Larson, L.R.; Usher, L.E.; Chapmon, T. Surfers as environmental stewards: Understanding place-protecting behavior at Cape Hatteras National Seashore. Leis. Sci. 2018, 40, 442-465. [CrossRef]

44. Poudel, S.; Nyaupane, G.P. Understanding environmentally responsible behaviour of ecotourists: The Reasoned Action Approach. Tour. Plan. Dev. 2017, 14, 337-352. [CrossRef]

45. Baird, T.; Hall, C.M.; Castka, P. New Zealand winegrowers attitudes and behaviours towards wine tourism and sustainable winegrowing. Sustainability 2018, 10, 797. [CrossRef]

46. Alibabic, V.; Jokic, S.; Mujic, I.; Rudic, D.; Bajramovic, M.; Jukic, H. Attitudes, behaviors, and perception of consumers' from northwestern Bosnia and Herzegovina toward food products on the market. Procedia-Soc. Behav. Sci. 2011, 15, $2932-2937$. [CrossRef]

47. Capitello, R.; Bazzani, C.; Begalli, D. Consumer personality, attitudes and preferences in out-of-home contexts. Int. J. Wine Bus. Res. 2019, 31, 48-67. [CrossRef]

48. Forbes, S.L.; Cohen, D.A.; Cullen, R.; Wratten, S.D.; Fountain, J. Consumer attitudes regarding environmentally sustainable wine: An exploratory study of the New Zealand marketplace. J. Clean. Prod. 2009, 17, 1195-1199. [CrossRef]

49. Jorge, E.; Lopez-Valeiras, E.; Gonzalez-Sanchez, M.B. The role of attitudes and tolerance of ambiguity in explaining consumers' willingness to pay for organic wine. J. Clean. Prod. 2020, 257, 120601. [CrossRef]

50. Pomarici, E.; Vecchio, R. Millennial generation attitudes to sustainable wine: An exploratory study on Italian consumers. J. Clean. Prod. 2014, 66, 537-545. [CrossRef]

51. Rojas-Méndez, J.I.; Le Nestour, M.; Rod, M. Understanding Attitude and Behavior of Canadian Consumers Toward Organic Wine. J. Food Prod. Mark. 2015, 21, 375-396. [CrossRef]

52. Holden, E.; Linnerud, K. Environmental attitudes and household consumption: An ambiguous relationship. Int. J. Sustain. Dev. 2010, 13, 217-231. [CrossRef] 
53. Esteban Ibáñez, M.; Musitu Ferrer, D.; Amador Muñoz, L.V.; Claros, F.M.; Olmedo Ruiz, F.J. University as Change Manager of Attitudes towards Environment (The Importance of Environmental Education). Sustainability 2020, 12, 4568. [CrossRef]

54. Kovačič, G.; Brečko Grubar, V. Knowledge of sustainable development among geography students in Slovenia. Acta Geogr. Slov. 2016, 56, 101-119. [CrossRef]

55. Budeanu, A. Sustainable tourist behaviour-A discussion of opportunities for change. Int. J. Consum. Stud. 2007, 31, 499-508 [CrossRef]

56. Ajzen, I. The theory of planned behavior: Frequently asked questions. Hum. Behav. Emerg. Technol. 2020, 2, 314-324. [CrossRef]

57. Ajzen, I. The theory of planned behaviour: Reactions and reflections. Psychol. Health 2011, 26, 1113-1127. [CrossRef] [PubMed]

58. Ajzen, I. Attitudinal vs. Normative Messages: An Investigation of the Differential Effects of Persuasive Communications on Behavior. Sociometry 1971, 34, 263-280. [CrossRef]

59. Becker, E.A.; Gibson, C. Fishbein and Ajzen's theory of reasoned action: Accurate prediction of behavioral intentions for enrolling in distance education courses. Adult Educ. Q. 1998, 49, 43-55. [CrossRef]

60. Boguszewicz-Kreft, M.; Kuczamer-Klopotowska, S.; Kozlowski, A.; Ayci, A.; Abuhashesh, M. The Theory of Planned Behaviour in Medical Tourism: International Comparison in the Young Consumer Segment. Int. J. Envrion. Res. Public Health 2020, 17, 1626. [CrossRef]

61. Ashraf, M.S.; Hou, F.; Kim, W.G.; Ahmad, W.; Ashraf, R.U. Modeling tourists' visiting intentions toward ecofriendly destinations: Implications for sustainable tourism operators. Bus. Strategy Environ. 2019, 29, 54-71. [CrossRef]

62. Karl, M. Risk and Uncertainty in Travel Decision-Making: Tourist and Destination Perspective. J. Travel Res. 2016, 57, 129-146. [CrossRef]

63. Um, S.; Crompton, J.L. The Roles of Perceived Inhibitors and Facilitators in Pleasure Travel Destination Decisions. J. Travel Res. 1992, 30, 18-25. [CrossRef]

64. Currie, R.R.; Wesley, F.; Sutherland, P. Going where the Joneses go: Understanding how others influence travel decision-making. Int. J. Cult. Tour. Hosp. Res. 2008, 2, 12-24. [CrossRef]

65. Gardiner, S.; King, C.; Grace, D. Travel decision making: An empirical examination of generational values, attitudes, and intentions. J. Travel Res. 2013, 52, 310-324. [CrossRef]

66. Alderighi, M.; Bianchi, C.; Lorenzini, E. The impact of local food specialities on the decision to (re)visit a tourist destination: Market-expanding or business-stealing? Tour. Manag. 2016, 57, 323-333. [CrossRef]

67. Jung, T.; Ineson, E.M.; Kim, M.; Yap, M.H.T. Influence of festival attribute qualities on Slow Food tourists' experience, satisfaction level and revisit intention. J. Vacat. Mark. 2015, 21, 277-288. [CrossRef]

68. Stylos, N.; Vassiliadis, C.A.; Bellou, V.; Andronikidis, A. Destination images, holistic images and personal normative beliefs: Predictors of intention to revisit a destination. Tour. Manag. 2016, 53, 40-60. [CrossRef]

69. Um, S.; Chon, K.; Ro, Y. Antecedents of revisit intention. Ann. Tour. Res. 2006, 33, 1141-1158. [CrossRef]

70. Hyde, K.F.; Decrop, A. New perspectives on vacation decision making. Int. J. Cult. Tour. Hosp. Res. 2011, 5, 103-111. [CrossRef]

71. Björk, P.; Jansson, T. Travel decision-making: The role of habit. Tour. Int. Multidiscip. J. Tour. 2008, 3, 11-34.

72. Verplanken, B.; Orbell, S. Reflections on past behavior: A self-report index of habit strength 1. J. Appl. Soc. Psychol. 2003, 33, 1313-1330. [CrossRef]

73. Ricci, F.; Del Missier, F. Supporting travel decision making through personalized recommendation. In Designing Personalized User Experiences in eCommerce; Springer: Berlin/Heidelberg, Germany, 2004; pp. 231-251.

74. Dwityas, N.A.; Briandana, R. Social media in travel decision making process. Int. J. Humanit. Soc. Sci. 2017, 7, $291-292$.

75. Hung, K.; Petrick, J.F. Testing the effects of congruity, travel constraints, and self-efficacy on travel intentions: An alternative decision-making model. Tour. Manag. 2012, 33, 855-867. [CrossRef]

76. Juvan, E.; Dolnicar, S. Measuring environmentally sustainable tourist behaviour. Ann. Tour. Res. 2016, 59, 30-44. [CrossRef]

77. Kroesen, M. Exploring people's viewpoints on air travel and climate change: Understanding inconsistencies. J. Sustain. Tour. 2013, 21, 271-290. [CrossRef]

78. Hobson, K. Competing discourses of sustainable consumption: Does the'rationalisation of lifestyles' make sense? Environ. Politics 2002, 11, 95-120. [CrossRef]

79. Paunovic, I.; Dressler, M.; Mamula Nikolic, T.; Popovic Pantic, S. Developing a Competitive and Sustainable Destination of the Future: Clusters and Predictors of Successful National-Level Destination Governance across Destination Life-Cycle. Sustainability 2020, 12, 4066. [CrossRef]

80. Chang, S.-H.; Hernández-Díaz, R.J.; Lo, W.-S. The Impact of Low-Carbon Service Operations on Responsible Tourist Behavior: The Psychological Processes of Sustainable Cultural Tourism. Sustainability 2020, 12, 12. [CrossRef]

81. Paunović, I.; Jovanović, V. Sustainable mountain tourism in word and deed: A comparative analysis in the macro regions of the Alps and the Dinarides. Acta Geogr. Slov. 2019, 59, 59-69. [CrossRef]

82. Garay, L.; Font, X.; Corrons, A. Sustainability-Oriented Innovation in Tourism: An Analysis Based on the Decomposed Theory of Planned Behavior. J. Travel Res. 2018, 58, 622-636. [CrossRef]

83. Paunović, I.; Jovanović, V. Implementation of Sustainable Tourism in the German Alps: A Case Study. Sustainability 2017, 9, 226. [CrossRef]

84. Lumsdon, L.M.; McGrath, P. Developing a conceptual framework for slow travel: A grounded theory approach. J. Sustain. Tour. 2011, 19, 265-279. [CrossRef] 
85. Andereck, K.L. Tourists' perceptions of environmentally responsible innovations at tourism businesses. J. Sustain. Tour. 2009, 17, 489-499. [CrossRef]

86. Budeanu, A. Impacts and responsibilities for sustainable tourism: A tour operator's perspective. J. Clean. Prod. 2005, 13, 89-97. [CrossRef]

87. Pulido-Fernández, J.I.; López-Sánchez, Y. Are tourists really willing to pay more for sustainable destinations? Sustainability 2016, 8, 1240. [CrossRef]

88. Dolnicar, S.; Matus, K. Are green tourists a managerially useful target segment? J. Hosp. Leis. Mark. 2008, 17, 314-334. [CrossRef]

89. Hanna, P.; Adams, M. Positive self-representations, sustainability and socially organised denial in UK tourists: Discursive barriers to a sustainable transport future. J. Sustain. Tour. 2019, 27, 189-206. [CrossRef]

90. Dolnicar, S.; Leisch, F. An investigation of tourists' patterns of obligation to protect the environment. J. Travel Res. 2008, 46, 381-391. [CrossRef]

91. Han, H. Travelers' pro-environmental behavior in a green lodging context: Converging value-belief-norm theory and the theory of planned behavior. Tour. Manag. 2015, 47, 164-177. [CrossRef]

92. Landon, A.C.; Woosnam, K.M.; Boley, B.B. Modeling the psychological antecedents to tourists' pro-sustainable behaviors: An application of the value-belief-norm model. J. Sustain. Tour. 2018, 26, 957-972. [CrossRef]

93. Han, J.; Lee, M.; Hwang, Y.-S. Tourists' Environmentally Responsible Behavior in Response to Climate Change and Tourist Experiences in Nature-Based Tourism. Sustainability 2016, 8, 644. [CrossRef]

94. Iniesta-Bonillo, M.A.; Sánchez-Fernández, R.; Jiménez-Castillo, D. Sustainability, value, and satisfaction: Model testing and cross-validation in tourist destinations. J. Bus. Res. 2016, 69, 5002-5007. [CrossRef]

95. Buffa, F. Young Tourists and Sustainability. Profiles, Attitudes, and Implications for Destination Strategies. Sustainability 2015, 7, 14042-14062. [CrossRef]

96. Kaplowitz, M.D.; Lupi, F.; Yeboah, F.K.; Thorp, L.G. Exploring the middle ground between environmental protection and economic growth. Public Underst. Sci. 2013, 22, 413-426. [CrossRef]

97. Gurumurthy, K.M.; Kockelman, K.M. Modeling Americans' autonomous vehicle preferences: A focus on dynamic ride-sharing, privacy \& long-distance mode choices. Technol. Forecast. Soc. Chang. 2020, 150, 119792.

98. Endler, C.; Oehler, K.; Matzarakis, A. Vertical gradient of climate change and climate tourism conditions in the Black Forest. Int. J. Biometeorol. 2010, 54, 45-61. [CrossRef]

99. Ioannides, D.; Debbage, K. Post-Fordism and flexibility: The travel industry polyglot. Tour. Manag. 1997, 18, 229-241. [CrossRef]

100. Anuar, F.; Gretzel, U. Privacy Concerns in the Context of Location-Based Services for Tourism. In Proceedings of the ENTER 2011 Conference, Innsbruck, Austria, 26-28 January 2011.

101. Zheng, F.; Li, J.; Van Zuylen, H.; Liu, X.; Yang, H. Urban travel time reliability at different traffic conditions. J. Intell. Transp. Syst. 2018, 22, 106-120. [CrossRef]

102. Atadil, H.A.; Sirakaya-Turk, E.; Meng, F.; Decrop, A. Exploring travelers' decision-making styles. Int. J. Contemp. Hosp. Manag. 2018, 30, 618-636. [CrossRef]

103. Dickinson, J.E.; Robbins, D.; Lumsdon, L. Holiday travel discourses and climate change. J. Transp. Geogr. 2010, 18, 482-489. [CrossRef]

104. Hooper, D.; Coughlan, J.C.; Mullen, M.R. Structural Equation Modelling: Guidelines for Determining Model Fit. Electron. J. Bus. Res. Methods 2008, 6, 53-60.

105. Shi, D.; Lee, T.; Maydeu-Olivares, A. Understanding the Model Size Effect on SEM Fit Indices. Educ. Psychol. Meas. 2019, 79, 310-334. [CrossRef] [PubMed]

106. Sanbonmatsu, D.M.; Prince, K.C.; Vanous, S.; Posavac, S.S. The multiple roles of attitudes in decision making. In The Routines of Decision Making; Psychology Press: Hove, UK, 2014; pp. 131-146.

107. Lindell, M.K.; Whitney, D.J. Accounting for common method variance in cross-sectional research designs. J. Appl. Psychol. 2001, 86, 114. [CrossRef] [PubMed]

108. Chang, S.-J.; Van Witteloostuijn, A.; Eden, L. From the Editors: Common Method Variance in International Business Research; Springer: Berlin/Heidelberg, Germany, 2010.

109. Tehseen, S.; Ramayah, T.; Sajilan, S. Testing and controlling for common method variance: A review of available methods. J. Manag. Sci. 2017, 4, 142-168. [CrossRef]

110. Eichhorn, B.R. Common method variance techniques. In Cleveland State University, Department of Operations E Supply Chain Management; SAS Institute Inc: Cleveland, OH, USA, 2014; pp. 1-11.

111. Boniface, B.; Cooper, C. Worldwide Destinations: The Geography of Travel and Tourism; Elsevier Ltd.: Oxford, UK, 2009. 